Journal of Animal and Veterinary Advances 10 (2): 180-184, 2011

ISSN: $1680-5593$

(C) Medwell Journals, 2011

\title{
Plasmid Analysis of Fluoroquinolone Resistant Commensal $E$. coli from Faecal Samples of Apparently Healthy Cattle in Ado-Ekiti, Ekiti-State
}

\author{
${ }^{1}$ A.O. Ajayi, ${ }^{2}$ O.A. Olowe and ${ }^{1,3} \mathrm{O}$. Famurewa \\ ${ }^{1}$ Department of Microbiology, University of Ado-Ekiti, P.M.B. 5363, Ado-Ekiti, Nigeria \\ ${ }^{2}$ Department of Medical Microbiology and Parasitology, College of Health Sciences, \\ Ladoke Akintola University of Technology, Osogbo, Nigeria \\ ${ }^{3}$ College of Science, Engineering and Technology, Osun-State University, P.M.B. 4494 , \\ Oke-Baale, Osogbo, Nigeria
}

\begin{abstract}
This study was carried out to investigate the prevalence of fluoroquinolone resistance and plasmid carriage among isolates of commensal $E$. coli isolated from faeces of cattle. Fresh faecal samples were collected from apparently healthy cattle and were cultured on eosine methylene blue agar plates from which 500 commensal $E$. coli isolates were recovered and characterised using standard biochemical tests. Using protocol recommended by the Clinical Laboratory Science Institute, all isolates were examined for their susceptibility to five fluoroquinolones: norfloxacine $(5 \mu \mathrm{g})$, levofloxacine $(5 \mu \mathrm{g})$, pefloxacine $(5 \mu \mathrm{g})$, ofloxacine $(5 \mu \mathrm{g})$ and ciprofloxacine $(5 \mu \mathrm{g})$. The resistance among isolates against the fluoroquinolones are as follows: pefloxacine, $99(19.8 \%)$; ciprofloxacine, $55(11.0 \%)$; norfloxacine, $39(7.5 \%)$; ofloxacine $26(5.2 \%)$ while the isolates showed least resistance against levofloxacine $23(4.6 \%)$. The organisms also showed considerable multiple fluoroquinolone-resistance and sixteen different fluoroquinolone-resistance phenotypes were observed with the most prominent phenotype observed to be Cip-Nor-Ofx-Pef-Lev. Thirteen representative isolates were selected and examined for the presence of plasmids. Twelve of the representative isolates carried multiple plasmids while one isolate carried a single plasmid. After mating experiments, plasmids were transferred to recipient strains at high frequencies of conjugation. These findings have serious public health implications as fluoroquinolone-resistant bacteria could be shed into the immediate environments, food and drinking water sources.
\end{abstract}

Key words: Prevalence, fluoroquinolone resistance, plasmid, eosine, phenotype, Nigeria

\section{INTRODUCTION}

The fluoroquinolones are a group of synthetic antimicrobials that possess a broad-spectrum of activity against gram-positive and negative bacteria and are one of the most prescribed families of antimicrobials worldwide (Ip et al., 2006; Morgan-Linnell et al., 2009). Historically, the onset of the use of fluoroquinolones in humans signalled effective prevention and control of infections, most especially pneumonia, intestinal infections, urinary tract infections and other life threatening infections (Collignon and Angulo, 2006). Furthermore, fluoroquinolones were subsequently licensed for use in animal medicine to prevent and control infections, enhance increase in animal weight and maintain overall quality of animal health with consequent increase in productivity (Riddle et al., 2000).

In some cases some fluoroquinolones are licensed exclusively for use in poultry and birds, cattle and canines
(Iovine and Blaser, 2004) and they have been highly effective for treatment of animal diseases such as mastitis, respiratory tract infections, urinary tract infections and bronchitis (Guardabassi et al., 2004). However, the emergence of bacterial pathogens and other commensal bacteria which inhabit the gut and show resistance to fluoroquinolones has compromised the effectiveness and use of the fluoroquinolones and this phenomenon have been attributed to overdependence on flouroquinolones in veterinary and human medicine.

The common mechanism of resistance against quinolones and fluoroquinolones include antibiotic efflux pumps, enzymatic modifications, decreased permeability in the porin channels on bacterial cells and alteration of enzymatic targets in bacterial sells (Ruiz, 2003; Hawkey, 2003). More recently, plasmids harbouring genes that confer resistance against fluoroquinolones have been described as the genetic mechanism for resistance among bacteria from animal origin. In addition, chromosomally

Corresponding Author: O. Famurewa, Department of Microbiology, University of Ado-Ekiti, P.M.B. 5363, Ado-Ekiti, Nigeria 
mediated resistance against fluoroquinolones was believed to be the major mechanism before to the discovery of plasmid-mediated resistance to fluoroquinolones (Nordmann and Poirel, 2005; Venturini et al., 2009). Similarly, Fortini et al. (2009) reported that novel genetic elements, most especially plasmids are present among bacteria isolated from food producing animals and their presence often constitute serious public health threat due to the relatively high frequency at which the genetic elements are transferred.

In this study, we seek to determine the plasmid profile of commensal $E$. coli isolated from cattle which showed resistance against fluoroquinolones in the study area where meat is considered essential to human diet.

\section{MATERIALS AND METHODS}

Collection and processing of samples: Faecal samples were collected from apparently healthy cattle at Igbo-Adere, Ado-Ekiti, Ekiti-State and plated directly onto Eosin Methylene agar (EMB) plates. Five hundred isolates of commensal $E$. coli were recovered and identified on the basis of their characteristic green metallic sheen and biochemical tests as described by Olutiola et al. (2001).

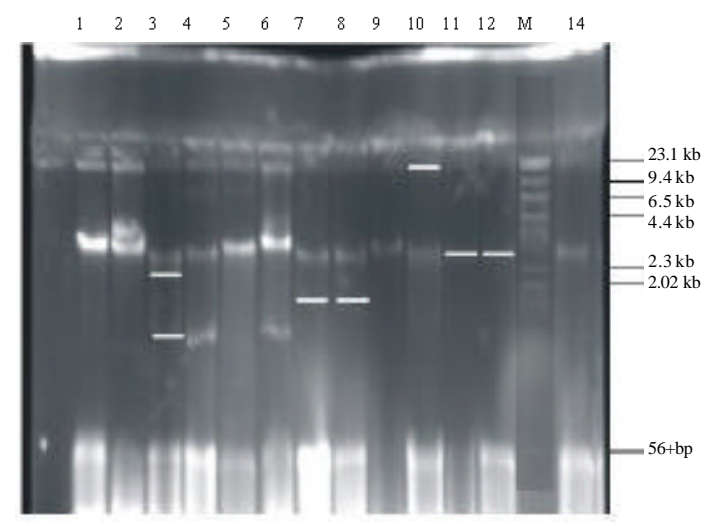

Fig. 1: Plasmid profiles of representative isolates of fluoroquinolone resistant $E$. coli (Lane 1: E464, $22.7 \mathrm{~kb}, 3.7 \mathrm{~kb}, 564 \mathrm{bp}$; Lane 2: E22.7 kb, $3.9 \mathrm{~kb}, 3.7$ kb; Lane 3: E626, 22.7 kb, 3.9 kb, 3.7 kb; Lane 4: E580, $22.7 \mathrm{~kb}, 3.8 \mathrm{~kb}, 1.67 \mathrm{~kb}, 564 \mathrm{bp}$; Lane 5: E522, $22.7 \mathrm{~kb}, 3.9 \mathrm{~kb}, 564 \mathrm{bp}$; Lane 6: E466, $22.7 \mathrm{~kb}, 3.9$ $\mathrm{kb}, 1.67 \mathrm{~kb}$; Lane 7: E467, $22.7 \mathrm{~kb}, 3.9 \mathrm{~kb}, 1.67 \mathrm{~kb}$; Lane 8: 3.4 kb, 1.98 kb, 564 bp; Lane 9: E406, 3.9 kb; Lane 10: E404, 2.27 kb, 3.4 kb, 564 bp; Lane 11: E295, 3.4 kb; Lane 12: E277, 3.4 kb, 564 bp; Lane M: Marker: Hind III digest; Lane 14: E80, 3.4 kb, 564 bp)
Antibiotic susceptibility testing: All test innocula were inoculated onto Mueller-Hinton broth $(0.5 \mathrm{McF}$ arland turbidity) from $24 \mathrm{~h}$ cultures. All bacterial isolates were tested for their susceptibility on Mueller-Hinton agar against five fluoroquinolones: norfloxacine $(5 \mu \mathrm{g})$, levofloxacine $(5 \mu \mathrm{g})$, pefloxacine $(5 \mu \mathrm{g})$, ofloxacine $(5 \mu \mathrm{g})$ and ciprofloxacine $(5 \mu \mathrm{g})$ (Oxoid, UK). Susceptibility tests were done using the agar disk diffusion method according to the recommendations of the Clinical Laboratory Science Institute (CLSI, 2008). The zones of inhibition were measured and compared with standard interpretative charts.

Plasmid analysis and mating experiment: Thirteen representative isolates were selected on the basis of their multiple fluoroquinolone resistance phenotypes and cultured overnight on Mueller-Hinton broth (Fig. 1). Plasmids DNA were extracted from cultured cells using the modified alkaline lysis protocol method (Bimboim and Dolly, 1979; Johnson, 1998). The plasmid DNA was electrophoresed on $0.8 \%$ agarose gel stained with ethidium bromide and visualized by UV-transillumination. Plasmid sizes were estimated by comparing with standard DNA bands obtained from Lambda Hind III digest. The isolates that were confirmed to carry plasmid (s) were further selected and conjugated with recipient strain E. coli 25922 and transconjugants were selected on Mueller-Hinton plates containing tetracycline.

\section{RESULTS}

Results obtained in this study indicate that resistance against pefloxacine was highest with $99(19.8 \%)$ isolates showing resistance to the antibiotic while resistance against levofloxacine was least (Table 1). Some of the isolates showed considerable multiple fluoroquinoloneresistance and 16 different fluoroquinolone-resistance

Table 1: Susceptibility to fluoroquinolones of commensal $E$. coli isolated from apparently healthy cattle

\begin{tabular}{lc}
\hline Antibiotics & Number (\%) \\
\hline Pefloxacine & $99(19.8)$ \\
Ciprofloxacine & $55(11.0)$ \\
Norfloxacine & $39(7.8)$ \\
Ofloxacine & $26(5.2)$ \\
Levofloxacine & $23(4.6)$ \\
\hline
\end{tabular}

Table 2: Multiple fluoroquinolone-resistance among commensal $E$. coli isolates from apparently healthy cattle

\begin{tabular}{lc}
\hline Antibiotics & Number $(\%) \mathrm{n}=500$ \\
\hline Pefloxacine & $99(19.8)$ \\
Ciprofloxacine & $55(11.0)$ \\
Norfloxacine & $39(7.8)$ \\
Ofloxacine & $26(5.2)$ \\
Levofloxacine & $23(4.6)$ \\
\hline
\end{tabular}


Table 3: Multiple fluoroquinolone-resistance phenotypes among commensal E. coli isolates from apparently healthy cattle

No. of No. of

\begin{tabular}{|c|c|c|c|c|c|c|c|}
\hline \multirow{2}{*}{$\frac{\mathrm{S} / \mathrm{N}}{1}$} & \multirow{2}{*}{$\begin{array}{l}\begin{array}{c}\text { No. of } \\
\text { fluoroquinolones }\end{array} \\
2\end{array}$} & \multicolumn{5}{|c|}{------Resistance phenotypes--------- } & \multirow{2}{*}{$\begin{array}{c}\begin{array}{l}\text { No. of } \\
\text { isolates }\end{array} \\
1\end{array}$} \\
\hline & & Cip & Nor & & & & \\
\hline 2 & & Cip & Pef & & & & 3 \\
\hline 3 & & Lev & Pef & & & & 1 \\
\hline 4 & & Pef & Nor & & & & 2 \\
\hline 5 & & Pef & Ofx & & & & 3 \\
\hline Total & & & & & & & 10 \\
\hline 6 & 3 & Cip & Pef & Nor & & & 9 \\
\hline 7 & & Cip & Pef & Ofx & & & 1 \\
\hline 8 & & Lev & Cip & Nor & & & 1 \\
\hline 9 & & Lev & Cip & Ofx & & & 1 \\
\hline 10 & & Lev & Cip & Pef & & & 3 \\
\hline 11 & & Lev & Nor & Ofx & & & 4 \\
\hline 12 & & Pef & Nor & Ofx & & & 1 \\
\hline Total & & & & & & & 20 \\
\hline 13 & 4 & Cip & Pef & Ofx & Nor & & 5 \\
\hline 14 & & Lev & Cip & Nor & Ofx & & 1 \\
\hline 15 & & Lev & Cip & Pef & Ofx & & 1 \\
\hline Total & & & & & & & 7 \\
\hline 16 & 5 & Lev & Cip & Pef & Nor & ofx & 23 \\
\hline Total & & & & & & & 23 \\
\hline
\end{tabular}

Cip-Ciprofloxacine, Lev-Levofloxacine, Nor-Norfloxacine, Ofx-Ofloxacine, Pef-Pefloxacine

Table 4: Plasmid profile of fluoroquinolone resistant isolates

\begin{tabular}{llll}
\hline Lanes & $\begin{array}{c}\text { Isolate } \\
\text { code }\end{array}$ & \multicolumn{1}{c}{$\begin{array}{c}\text { Plasmid bands } \\
\text { (Approx.) }\end{array}$} & $\begin{array}{c}\text { Fluoroquinolone } \\
\text { resistance phenotypes }\end{array}$ \\
\hline 1 & E646 & $22.7 \mathrm{~kb}, 3.7 \mathrm{~kb}, 564 \mathrm{bp}$ & Pef-Cip \\
2 & E625 & $22.7 \mathrm{~kb}, 3.9 \mathrm{~kb}, 3.7 \mathrm{~kb}$ & $\begin{array}{l}\text { Pef-Ofx-Nor } \\
\text { Pef-Cip }\end{array}$ \\
3 & E626 & $22.7 \mathrm{~kb}, 3.8 \mathrm{~kb}, 2.3 \mathrm{~kb}$, & \\
& & $1.67 \mathrm{~kb}, 564 \mathrm{bp}$ & \\
4 & E580 & $22.7 \mathrm{~kb}, 3.8 \mathrm{~kb}, 1.67 \mathrm{~kb}, 564 \mathrm{bp}$ & Pef-Ofx-Cip-Lev \\
5 & E522 & $22.7 \mathrm{~kb}, 3.9 \mathrm{~kb}, 564 \mathrm{bp}$ & Nor \\
6 & E466 & $22.7 \mathrm{~kb}, 3.9 \mathrm{~kb}, 1.67 \mathrm{~kb}$ & Pef \\
7 & E467 & $3.4 \mathrm{~kb}, 1.98 \mathrm{~kb}, 564 \mathrm{bp}$ & Ofx-Nor-Lev \\
8 & E440 & $3.4 \mathrm{~kb}, 1.98 \mathrm{~kb}, 564 \mathrm{bp}$ & Pef \\
9 & E406 & $3.9 \mathrm{~kb}$ & Pef \\
10 & E404 & $22.7 \mathrm{~kb}, 3.4 \mathrm{~kb}, 564 \mathrm{bp}$ & Pef \\
11 & E295 & $3.4 \mathrm{~kb}$ & Cip \\
12 & E277 & $3.4 \mathrm{~kb}, 564 \mathrm{bp}$ & Pef-Cip \\
M & Marker: & - & - \\
& Hind III Digest & \\
14 & E80 & $3.4 \mathrm{~kb}, 564 \mathrm{bp}$ & Ofx \\
\hline
\end{tabular}

Amp-Ampicillin, Col-Colistin, Cot-Cotrimoxazole, Gen-Gentamicin, NalNalidixic-acid, Nit-Nitrofurantoin, Tet-Tetracycline, Strep-Streptomycin, Pef-Pefloxacine, Ofx-Ofloxacine, Cip-Ciprofloxacine, Lev-Levofloxacine, Nor-Norfloxacine

patterns were observed among isolates that were confirmed to show multiple fluoroquinolone resistance (Table 2). The most predominant resistance patterns were Lev-Cip-Pef-Nor-Ofx (Table 3). Multiple fluoroquinoloneresistant isolates were defined as those isolates that showed resistance against a minimum of two fluoroquinolones. The overall plasmid profiles of the representative isolates revealed that 12 of the 13 representative isolates carried multiple plasmids while the remaining one carried only one plasmid (E295, Lane 11); with molecular weight of plasmids ranging between $564 \mathrm{bp}$ and $22.3 \mathrm{~kb}$ (Table 4). Lambda Hind III digest was used to estimate the molecular weight of all bands resolved after
Table 5: Result for transconjugants selected among fluoroquinoloneresistant $E$. coli

\begin{tabular}{lccc}
\hline Lanes & $\begin{array}{c}\text { Isolate } \\
\text { code }\end{array}$ & $\begin{array}{c}\text { Frequency of conjugation } \\
\text { (Transconjugants/donor cells) }\end{array}$ & $\mathrm{MIC}\left(\mathrm{mg} \mathrm{L}^{-1}\right)$ \\
\hline 1 & E646 & $1.0 \times 10^{-4}$ & 32 \\
2 & E625 & $1.4 \times 10^{-3}$ & 32 \\
3 & E626 & $1.9 \times 10^{-4}$ & $>64$ \\
4 & E580 & $2.2 \times 10^{-5}$ & 32 \\
5 & E522 & $1.6 \times 10^{-4}$ & 16 \\
6 & E466 & $2.5 \times 10^{-2}$ & 32 \\
7 & E467 & $2.3 \times 10^{-5}$ & 64 \\
8 & E440 & $9.0 \times 10^{-4}$ & 64 \\
9 & E406 & 00 & 64 \\
10 & E404 & $2.8 \times 10^{-4}$ & 32 \\
11 & E295 & $2.7 \times 10^{-5}$ & 16 \\
12 & E277 & $1.6 \times 10^{-3}$ & 64 \\
14 & E80 & $1.9 \times 10^{-3}$ & 64 \\
\hline
\end{tabular}

electrophoresis. In the mating experiments, plasmids were successfully transferred to the plasmid-free recipient E. coli 25922 at varied frequencies of conjugation and MIC of transconjugants for tetracycline at a minimum of $16 \mathrm{mg} \mathrm{L}^{-1}$. One of the isolates carrying plasmids did not transfer it to the recipient (Table 5).

\section{DISCUSSION}

This study has demonstrated that the incidence of fluoroquinolone-resistance among commensal $E$. coli isolated form apparently healthy cattle is relatively high with $20 \%(99 / 500)$ of the multiple fluoroquinoloneresistant isolates showing resistance to the antibiotic. This could be related to the use of fluoroquinolones and other related brooad-spectrum agents in veterinary practice in the study location which exposes the bacteria to a selection pressure that favours the emergence of fluoroquinolone-resistant bacteria in the gut of the animals prior to slaughter. There are previous reports that have shown the increasing incidence of fluoroquinolone resistance among bacteria of animal origins and this study appears to be in accordance with such studies (Nordmann and Poirel, 2005; Collignon and Angulo, 2006). Food animals particularly cattle, swine sheep and birds are routinely fed with low doses of antibiotics through food and water to promote growth and expedite weight gain (Phillips et al., 2004; Scheider and Garrot, 2010).

Commensal $E$. coli in cattle and other animals is often used as an indicator organism to access the extent and type of resistance in the gastrointestinal tract since it plays a dynamic role in the ecology of multi-drug resistance bacteria and have been proven to be a reservoir of resistance (Van Donkersgoed et al., 2003; Sharma et al., 2008). The incidence of resistance against pefloxacine was highest while the organisms demonstrated the least resistance against levofloxacine among other antibiotics that were tested. In most cases of resistance shown by 
bacteria against antimicrobials, the relative frequency of resistance to antibiotics is quite often is an indication of the extent of usage of antibiotics (Sharma et al., 2008).

Multiple antibiotic resistance is defined as resistance against a minimum of two fluoroquinolones. Some of the isolates showed multiple-antibiotic resistance and studies have shown increasing incidence of fluoroquinolone resistance among enteric bacteria of animal origin (White et al., 2000). This is worrisome in view of the limitations that may be imposed on the options of antibiotics that may be used not only in animal medicine but also in human medicine.

A very high level of detection of plasmids was observed in this present study as all representative isolates harboured detectable plasmids with sizes between $564 \mathrm{bp}$ and $22.3 \mathrm{~kb}$ (Fig. 1). Twelve representative fluoroquinolone-resistant isolates harboured multiple plasmids while only one isolate carried one plasmid. The high rate of detection of multiple plasmids among the bacteria could be responsible for the high incidence of fluoroquinolone resistance among the isolates as observed in this study. A similar study by Smith et al. (2003) showed that multiple fluoroquinolone-resistant commensal $E$. coli isolated from apparently healthy animals also carry multiple plasmids.

Sherley et al. (2004) confirmed that an unusually high incidence of antibiotic resistance among enteric bacteria of animal origin is usually predicated on the presence of multiple-plasmids which usually encode genes for antimicrobial resistance. Recent studies have also characterised plasmids that encode fluoroquinoloneresistance among bacteria particularly $E$. coli and Salmonella from clinical and veterinary sources (Fortini et al., 2009; Gutierrez et al., 2009; Ma et al., 2009; Cerquetti et al., 2009).

The presence of plasmids in fluoroquinolone resistant isolates is a worrisome phenomenon and it points towards a serious public health threat within the immediate human population (Venturini et al., 2009). Fluoroquinolone resistance genes have been found on plasmids carried by ehteric bacteria isolated from chicken and other food animals (Kehrenberg et al., 2006; Avsaroglu et al., 2007).

Most plasmids that encode fluoroquinoloneresistance are conjugative and self-transmissible-a characteristic that ensures that such plasmids spread among bacterial population. By implication, such fluoroquinolone-resistant genes sometimes carried on plasmids are constantly shed into immediate environment; contaminating food and drinking water meant for humans (Khachatourians, 1998).

\section{CONCLUSION}

In summary, this study has confirmed that the prevalence of fluoroquinolone resistance among $E$. coli isolated from cattle is relatively high and the incidence of carriage of plasmids in such isolates is correspondingly high and such plasmids are transferred at high frequency. This observation calls for proactive actions by government, health and animal care professionals to regulate consumption of antibiotics in animals and set up extensive surveillance to monitor the occurrence of fluoroquinolone-resistance among bacteria in food animals.

\section{REFERENCES}

Avsaroglu, M.D., R. Helmuth, E. Junker, S. Hertwig and A. Schroeter et al., 2007. Plasmid-mediated quinolone resistance conferred by qnrS1 in Salmonella enterica serovar virchow isolated from Turkish food of avian origin. J. Antimicrob. Chemother., 60: 1146-1150.

Birnboim, H.C. and J. Dolly, 1979. A rapid alkaline extraction for screening recombinant DNA. Nucleic Acid Res., 7: 1513-1523.

CLSI, 2008. Performance Standards for Antimicrobial Susceptibility Tests. Clinical Laboratory Science Institute, Wayne, PA.

Cerquetti, M., A. Garcia-Fernandez, M. Giufre, D. Fortini and M. Accogli et al., 2009. First report of plasmidmediated quinolone resistance determinant qnrS1 in an Escherichia coli strain of animal origin in Italy. Antimicrob. Agents Chemother., 53: 3112-3114.

Collignon, P. and F. Angulo, 2006. Fluoroquinoloneresistant E. coli: Food for tought. J. Infect. Dis., 194: 1-9.

Fortini, D., A. Garcia-Fernandez, K. Veldman, D. Mevius and A. Carratolli, 2009. Novel genetic environment of plasmid-mediated quinolone resistance gene qnrB2 in Salmonella bredeney from poultry. J. Antimicrob. Chemother., 64: 1332-1334.

Guardabassi, L., S. Schwartz and D.H. Lloyd, 2004. Pet animals as reservoirs of antimicrobial resistant bacteria. J. Antimicrob. Chemother., 54: 321-332.

Gutierrez, B., S. Herrera-Leon, J.A. Escudero, L. Hidalgo and R. Gonzalez-Sanz et al., 2009. Novel genetic environment of qnrB2 associated with TEM-1 and SHV-12 on pB1004, an IncHI2 plasmid in Salmonella bredeney BB1047 from Spain. J. Antimicrob. Chemother., 64: 1334-1336.

Hawkey, P.M., 2003. Mechanisms of quinolone action and microbial response. J. Antimicrob. Chemother., 51: S29-S35. 
Iovine, N.M. and M.J. Blaser, 2004. Antibiotics in animal feed and spread of resistant Campylobacter from poultry to humans. Emerg. Infect. Dis., 10: 1158-1159.

Ip, M., S.S.L. Chau, C. Fang, A. Qi and R.W.M. Lai, 2006. Rapid screening of fluoroquinolone resistance determinants in Streptococcus pneumoniae by PCR-restriction fragment length polymorphism and single-strand conformational polymorphism. J. Clin. Microbial., 44: 970-975.

Johnson, P., 1998. Plasmid Analysis. In: Molecular Bacteriology Protocols and Clinical Applications, Johnson, A.P. and N. Woodford (Eds.). Humana Press Inc., Totowa, pp: 51-62.

Kehrenberg, C., S. Friederichs, A.D. Jong, G.B. Michael and S. Schwarz, 2006. Identification of the plasmid-borne quinolone resistance gene $q n r \mathrm{~S}$ in Salmonella enteica serovar Infantis. J. Antimicrob. Chemother., 58: 18-22.

Khachatourians, G.G., 1998. Agricultural uses of antibiotics and the transfer of antibiotic resistant bacteria. Can. Med. Ass. J., 159: 1129-1136.

Ma, J., Z. Zeng, Z. Chen, X. Xu and X. Wang et al., 2009. High prevalence of plasmid-mediated quinolone resistance determinants $q n r, a a c(6)-I b-c r$ and $q e p \mathrm{~A}$ among ceftiofur-resistant Enterobacteriaceae isolates from companion and food-producing animals. Antimicrob. Agents. Chemother., 53: 519-524.

Morgan-Linnell, S.K., L.B. Boyd, D. Steffen and L. Zechiedrich, 2009. Mechanisms accounting for fluorocuinolne resistance in $E$. coli clinical isolates. Antimicrob. Agents Chemother., 53: 235-242.

Nordmann, P. and L. Poirel, 2005. Emergence of plasmid-mediated resistance to quinolones in Enterobacteriaceae. J. Antimicrob. Chemother., 56: 463-469.

Olutiola, P.O., O. Famurewa and H.G. Sonntag, 2001. Biochemical Reactions of Microorganisms. Bolabay Publications, Ikeja, Nigeria, pp: 157-177.

Phillips, I., M. Casewell, T. Cox, B. de Groot and C. Friis et al., 2004. Does the use of antibiotics in food animals pose a risk to human health: A critical review of published data. J. Antimicrob. Chemother., 53: $28-52$.
Riddle, C., C.L. Lemons, M.G. Papich and C. Altier, 2000. Evaluation of ciprofloxacin as a representative of veterinary fluoroquinolones in susceptibility testing. J. Clin. Microbiol., 38: 1636-1637.

Ruiz, J., 2003. Mechanisms of resistance to quinolones: Target alterations, decreased accumulation and DNA gyrase protection. J. Antimicrob. Chemother., 51: 1109-1117.

Scheider, K. and L. Garrot, 2010. Non-therapeutic uses of antibiotics in animal agriculture, corresponding resistance rates and what can be done about it. Center for Global Development.

Sharma, R., K. Munns, T. Alexancer, T. Entz and P. Mirzaagha et al., 2008. Diversity and distribiution of commensal faecal $E$. coli bacteria in beef cattle administered selected subtherapeutic antimicrobials in a feedlot setting. Applied Environ. Microbial., 74: $6178-6186$.

Sherley, M., D.M. Gardon and P.J. Collingnon, 2004. Evolution of multi-resistance plasmids in Australia clinical isolates of Escherichia coli. Microbiology, 150: 1539-1546.

Smith, S.I., O.O. Aboaba, P. Odeigha, K. Shodipo and J.A. Adeyeye et al., 2003. Plasmid profile of Esherichia coli 0157: H7 from apparently healthy animals. Afr. J. Biotechnol., 2: 322-324.

Van Donkersgoed, J., K. Manninen, A. Potter, S. McEwen and V. Bohaychuk et al., 2003. Antimicrobial susceptibility of hazard analysis critical control point Escherichia coli isolates from federally inspected beef processing plants in Alberta, Saskatchewan and Ontario. Can. Vet. J., 44: 723-728.

Venturini, C., S.A. Beatson, S.P. Djorjevic and M.J. Walker, 2009. Multiple antibiotic resistance gene recruitment onto the enterohemorrhagic Escherichia coli virulence plasmid. FASEB J., 10.1096/fj.09144972.

White, D.G., L.J.V. Pddock, J. Maurer, S. Zhao, V. Ricci and S.G. Thayer, 2000. Characterisation of fluoroquinolone resistance among veterinary isolates of avian E. coli. Antimicrob. Agents Chemother., 44: $2897-2899$. 